\title{
Wheat Gluten, Desirable or Dangerous Genes
}

\author{
Ewa Filip* and Małgorzata Kaplewska \\ Department of Molecular Biology and Cytology, University of Szczecin, Poland
}

*Corresponding author: Ewa Filip, Department of Molecular Biology and Cytology, The Institute for Research on Biodiversity, Faculty of Biology, University of Szczecin, Szczecin, Poland.

To Cite This Article: Ewa Filip. Wheat Gluten, Desirable or Dangerous Genes. Am J Biomed Sci \& Res. 2019 - 4(3). AJBSR.MS.ID.000794. DOI: $10.34297 / A J B S R .2019 .04 .000794$

Received: : July 18, 2019 | Published: July 29, 2019

\begin{abstract}
My opinion is issued to collect and broaden the information about gluten, or more precisely, whether its presence and properties should raise concerns. Knowledge about gluten has expanded considerably over the last dozen or so years. It is known that it is a large polymer consisting of a mixture of proteins. Gluten occurs in popular cereals such as wheat, spelt, barley, rye and oat. Works carried out by cereal breeding institutes require a continuous control of the presence of various forms of these proteins in wheat grain, because, firstly, there is a need to obtain fertile varieties with high grain quality parameters, and secondly, to improve the physical and chemical properties of farinaceous products. As it turned out, gluten, which brings many positive aspects in the breeding process of cereals, as well as in the production of bakery products, can become a cause of many problems for humans. According to many authors, apart from celiac disease, there are already over 50 other diseases, such as osteoporosis, autoimmune diseases, cancer and neurological diseases that are being associated with gluten effects.
\end{abstract}

\section{Introduction}

Gluten is a polymer composed of a mixture of at least 50 proteins [1]. There are about $20 \%$ of proteins in the endosperm of mature cereal grains such as wheat, rye, barley, triticale and oat, of which $80 \%$ are gluten proteins $[2,3]$. The biological role of gluten is to supply elements (carbon, nitrogen and sulfur) to germinating seeds [4]. The composition of gluten proteins in grains affects the technological quality of common wheat. The quantity and composition of gluten proteins such as gliadins and glutenins is responsible for flour baking quality in the bakery industry. These proteins constitute the "skeleton" of a kneaded dough and are responsible for physicochemical properties of gluten. Gluten in cakes is primarily responsible for flexibility and cohesion [2,3]. As it turned out, gluten that brings so much positive properties in the production process of bakery products may be the cause of many health problems.

Gluten consumed by humans most often in the form of bread and pasta is a high-calorie food. This caloric value together with the increase of glucose and insulin in the body contributes to the formation and deposition of visceral fat, most often in the regions of the abdomen, thighs and buttocks as well as diabetic complications and diseases [5].

The biochemical effect of visceral fat on the body carries a number of adverse changes. Among other things, it leads to an increase in low density lipoprotein (LDL cholesterol) responsible for the accumulation of atherosclerotic plaque, hypertension, heart diseases [6-9]. In the nervous system, it is responsible for the occurrence of temporal epilepsy [10], dementia [11], ataxia, neuropathy, gluten encephalopathy [12], worsening of autistic indices [13] and aggravation of schizophrenia [14]. In the digestive system, apart from intolerance, allergy and celiac disease, gluten [15] is the cause of increased hepatic enzyme secretion, may lead to liver inflammation, primary biliary cirrhosis and colitis and Crohn's disease [16]. Skin symptoms of the negative effect of gluten are primarily herpetic dermatitis (Duhring's disease) [17], acne [18], paraneoplastic syndrome, erythema nodosum, psoriasis, dermatomyositis and exacerbation of the genetic ichtiosis vulgaris (ichthyosis) [17]. It was also shown that gluten affects hair loss [19]. The influence of gluten in the female reproductive system may contribute to infertility, increased risk of low birth weight of a newborn, premature labor or habitual miscarriage [20] and increased prolactin production [21]. In addition, women suffering from celiac disease are predisposed to a shorter fertility period, caused by the later age of menstruation and a faster menopause [22]. In the case of men, gluten proteins may lead to erectile dysfunction and gynecomastia [23], caused by disturbances of estrogen production by visceral fat [24].

Symptoms in the sense organs include retinopathies, cataracts and dry eye syndrome [25], while systemic symptoms are anemia and vitamin deficiencies [26]. 
Unfortunately, consumption of bread and flour products carries the risk of body acidification [27]. Acidosis contributes to bone fragility, osteopenia, fractures and osteoporosis [28].

Gluten proteins contained in the endosperm of cereals also contribute to tumor formation in the human body. They may be a factor contributing to the formation of breast, prostate, lung and gastrointestinal cancers, especially gastrointestinal tumors, colon cancer and pancreatic cancer $[29,30]$.

People with autoimmune gluten intolerance may have other co-existing autoimmune diseases such as type 1 diabetes, hyperthyroidism, vitiligo, primary biliary cirrhosis, rheumatoid arthritis [31], iron deficiency anemia, osteopenia and osteoporosis, hyposplenism or IgA nephropathy [32].

Despite the many negative effects of gluten consumption, its introduction to the infant diet does not cause adverse effects in their psychomotor development [33]. Gliadin, on the other hand, contributes to the enhanced action of the human immune system through the influence on monocytes and their cytokine production [34].

Table 1: The overall cognitive effect of gluten.

\begin{tabular}{|c|c|c|c|}
\hline \multirow{18}{*}{ The effect of gluten } & \multirow{3}{*}{$\begin{array}{l}\text { Positive } \\
\text { Neutral }\end{array}$} & \multicolumn{2}{|c|}{ Glutenins are responsible for the physicochemical properties of the dough. } \\
\hline & & \multicolumn{2}{|c|}{ Gliadins affects the production of cytokines by monocytes of the human organism. } \\
\hline & & \multicolumn{2}{|c|}{ It does not affect the psychomotor development of babies fed with artificial and natural food. } \\
\hline & \multirow{15}{*}{ Negative } & \multirow{3}{*}{ It causes hypersensitivity and food intolerance } & Celiac disease \\
\hline & & & Food allergies \\
\hline & & & Non-celiac gluten hypersensitivity \\
\hline & & \multirow{3}{*}{ He is responsible for acidifying the organism } & Osteoporosis \\
\hline & & & Osteopenia \\
\hline & & & From brittle to ductile fracture of bone \\
\hline & & \multirow{8}{*}{ He is responsible for the accumulation of visceral fat. } & Diseases of the cardiovascular system \\
\hline & & & Diseases of the digestive system \\
\hline & & & Diseases of the nervous system \\
\hline & & & Diseases of the reproductive system \\
\hline & & & Diseases of the skin \\
\hline & & & Diseases of the sense organs \\
\hline & & & Cancers \\
\hline & & & Avitaminosis \\
\hline & & \multicolumn{2}{|c|}{ It is a factor in the formation of autoimmune diseases. } \\
\hline
\end{tabular}

The review of many scientific publications has expanded our knowledge on this subject (Table 1), and not only medical knowledge, but also of agricultural genetics, which in the last 50 years has transformed traditional wheat into a hybrid productprofitable, robust and efficient, but little related to the original. One should remember that biological and genetic modifications of wheat were introduced with good intentions. At the turn of the 1960 s, there was a fear of world overcrowding and hunger in in the West. It was decided to increase cereal cultivations; the US and other highly developed countries began to invest huge amounts in research aimed at improving plants and increasing yields. Breeding programs existing to this day, based on wheat genetics and biotechnology, have achieved success, and currently we have highly fertile wheat with good grain quality parameters (group A, B). A wide breeding program taking into account all directions, based on global gene resources, provides annually new, better forms of common wheat. 


\section{References}

1. Shewry PR, Tatham AS, Halford NG (1999) The prolamins of the Triticeae. In: Shewry PR, et al. (Eds.), Seed Proteins. Kluwer Academic Press, Netherlands p. 35-78.

2. D Ovidio R, Masci S (2004) The low-molecular-weight glutenin subunits of wheat gluten. Journal of Cereal Science 39(3): 321-339.

3. Gale K (2005) Diagnostic DNA markers for quality traits in wheat. Journal of Cereal Science 41(2): 181-192.

4. Anjum FM, Khan MR, Din A, Saeed M, Pasha I, et al. (2007) Wheat Gluten High Molecular Weight Glutenin Subunits-Structure, Genetics, and Relation to Dough Elasticity. J Food Sci 72(3): R56-63.

5. Jenkins DJ, Wolever TM, Taylor RH, Barker H, Fielden H, et al. (1981) Glycemic index of foods: a physiological basis for carbohydrate exchange. Am J Clin Nutr 34(3): 362-366.

6. Matsuzawa Y (2010) Establishment of a concept of visceral fat syndrome and discovery of adiponectin. Proc Jpn Acad Ser B Phys Biol Sci 86(2): 131-141.

7. Savage DB, Semple RK (2010) Recent insights into fatty liver, metabolic dys- lipidacmia and their links to insulin resistance. Curr Opin Lipidol 21(4): 329-336.

8. Therond P (2009) Catabolism of lipoproteins and metabolic syndrome Curr Opin Clin Nutr Metab Care 12(4): 366-371.

9. Adiels M, Olofsson S, Taskinen R, Boren J (2008) Overproduction of very low-density lipoproteins is the hallmark of the dyslipidemia in the metabolic syndrome. Arteroscler ThrombVasc Biol 28(7): 1225-1236.

10. Harper E, Moses H, Lagrange A (2007) Occult celiac disease presenting as epilepsy and MRI changes that responded to gluten-free diet. Neurology 68(7): 533-534.

11. Nicolls MR (2004) The dinical and biological relationship between type 2 diabetes mellitus and Alzheimer's disease. Curr Alzheimer Res 1(1): 47-54.

12. Hadjivassiliou M, Sanders DS, Grünewald RA, Woodroofe N, Boscolo S, et al. (2010) Gluten sensitivity: from gut to brain. Lancet Neurol 9(3): 318-330.

13. Millward C, Ferriter M, Calver S, Connell Jones G (2008) Gluten- and casein-frce diets for autistic spectrum disorder. Cochranc Database Syst Rev 16(2): CD003498.

14. Ylissides DN, Venulct A, Jenner FA (1986) A double-blind gluten-free/ glu- ten-load controlled trial in a secure ward population. Br J Psychiatry 148: 447-452.

15. Cielecka EK, Dereń K, Grzegorczyk A (2010) Food hypersensitivity, Allergy Asthma. Immunology 15 (3): 118-124.

16. Peters U, Askling J, Gridley G, Ekbom A, Linet M (2003) Causes of death in patients with celiac disease in a population-based Swedish cohort. Arch Intern Med 163(13): 1566-1572.

17. Abenavoli L, Proietti I, Leggio L, Ferrulli A, Vonghia L (2006) Cutaneous manifestations in celiac disease, World J Gastroenterol Feb 12(6): 843852.
18. Abulnaja KO (2009) Changes in the hormone and lipid profile of obese adolescent Saudi females with acne vulgaris. Braz J Med Biol Res 42(6): 501-505.

19. Corazza GR, Andreani ML, Venturo N, Bernardi M, Tosti A (1995) Celiac disease and alopecia areata: report of a new association. Gastroenterology I09(4): I333-1337

20. Waszczuk E, Homola W (2006) Reproductive Disorders and Celiac Disease, Adv Clin Exp Med 15(6): 1093-1098.

21. Pynnönen PA, Isometsä ET, Verkasalo MA, Kähkönen SA, Sipilä I, et al. (2005) Gluten-free diet may alleviate depressive and behavioural symptoms in adolescents with celiac disease: a prospective follow-up case-series study. BMC Psychiatry 5:14.

22. Milewicz T, Pulka M, Galicka Latała D, Rzepka E, Krzysiek J (2011) Celiac disease - celiac disease and fertility. Medical Review 68(9): 641-644.

23. Johnson RE, Murad MH (2009) Gynecomastia: pathophysiology, evaluation and management. Mayo Clin Proc 84(1 l): 1010-1015.

24. Lautenbach A, Budde A, Wrann CD, Teichmann B, Vieten G (2009) Obesity and the associated media- tors leptin, estrogen and IGF-I enhance the celi prolifcration and early tumorigenesis of breast cancer cells. Nutr Cancer 61(4): 484-491.

25. Stitt AW (2001) Advanced glycation: an important pathological event in diabetic and age related ocular disease. Br J Ophthalmol 85(6): 746-753.

26. Barton SH, Kelly DG, Murray JA (2007) Gastroenterol Clin N Am 36: $93-$ I08.

27. Sebastian A, Frassetto LA, Sellmeyer DE, Merriam RL, Morris RC (2002) Estimation of the net acid load of the diet of ancestral preagricultural Homo sapiens and their hominid ancestors. Am J Clin Nutr 76(6): 13081316.

28. Shane Anderson A, Loeser RF (2010) Why is osteoarthritis an agerelated disease? Best Pract Res Clin Rheumatol 24(1): 15-26.

29. Bengmark S (2007) Advanced glycation and lipoxidation end products - am- plifiers of inflammation. the role of food. JPEN J Parenter Enteral Nutr 3(5): 430-440.

30. West J, Logan RF, Smith CJ, Hubbard RB, Card TR (2004) Malignancy and mortality in people with coeliac disease: population based cohort study. BMJ 329(7468): 716-719.

31. Szalecki M (2009) Coexistence of diabetes and other autoimmune diseases, Pediatric Review. 39(4): 260-265.

32. Kaniewska M, Rydzewska G (2009) Celiac disease in adults-pathogenesis, clinical manifestations, coexistence with inflammatory bowel diseases and other immune-mediated diseases. Gastroenterological Review 4(4): 173-177.

33. Bednarek A, Mazurkiewicz C (2010) Incidence of infectious illnesses of respiratory system and parameters of physical and psychomotor development in infants according to the type of feeding. Hygeia Public Health 45(2): 156-163.

34. Jelinkova L, Tuckova L, Cinova J, Flegelova Z, Tlaskalova Hogenova L (2004) Gliadin stimulates human monocytes to production of IL-8 and TNF- $\alpha$ trough a mechanism involving NF-kappaB. FEBS Lett 571(1-3): $81-85$ 